\title{
Social representations of Brazilian Truth Commission on news comments
}

\author{
Representaciones sociales de la Comisión de la Verdad de Brasil \\ en los comentarios de noticias
}

\author{
Anderson Mathias Dias Santos \\ University of Paraíba \\ anderson.mathias@yahoo.com.br \\ José Joaquín Pizarro Carrasco \\ University of the Basque Country \\ jose.pizarro@ehu.eus \\ Lidiane Silva de Araújo \\ University of Campina Grande \\ lidianearaujojp@gmail.com
Adriele Vieira de Lima Pinto
University of Paraíba
adrielevieira_8@hotmail.com

Citation/Cómo citar: Dias Santos, Anderson Mathias; Pizarro Carrasco, José Joaquín; Silva de Araújo, Lidiane; Vieira de Lima Pinto, Adriele. 2021. "Social representations of Brazilian Truth Commission on news comments». Deusto Journal of Human Rights, No. 8: 83-102. doi: http://dx.doi.org/10.18543/djhr.2285.

Summary: Introduction. 1. Truth commissions: overcoming a violent past. 2. Social representations of history. 3. Public opinion, online interaction, and misinformation. 4. Method. 4.1. Procedure and sample. 4.2. Data analysis. 5. Results. 6. Discussion. 7. Conclusions. References.

Abstract: The study investigated the social representations of the Brazilian Truth Commission from the news comments about its final report released in December 2014. Method: Comments $(N=322)$ were collected in the three major newspapers websites in Brazil: "Folha de São Paulo", "O Globo" and "O Estado de São Paulo" during the 48 hours following the report's publication. They were submitted to a lexical analysis on the software Radicalized discourses justifying the violations and narratives denying the 
existence of a dictatorship were observed. Discussion: Results were in line with social media theories about online behavior, but they do not corroborate previous research on the social representations of the military regime and Truth Commissions in South America.

Keywords: collective memory, social representations of history, social media, transitional justice, truth commissions.

Resumen: El estudio investigó las representaciones sociales de la Comisión de la Verdad de Brasil a partir de los comentarios de las noticias sobre su informe final publicado en diciembre de 2014. Método: Se recogieron comentarios $(\mathrm{N}=322$ ) en los sitios web de los tres principales periódicos de Brasil: "Folha de São Paulo", "O Globo" y "O Estado de São Paulo" durante las 48 horas siguientes a la publicación del informe. Los comentarios se sometieron a un análisis léxico en el software Alceste. Resultados: Surgieron tres clases, todas ellas críticas a la Comisión de la Verdad. Se observaron discursos radicalizados que justifican las violaciones y narrativas que niegan la existencia de una dictadura. Discusión: Los resultados estuvieron en línea con las teorías sobre el comportamiento en línea, pero no corroboran las investigaciones sobre las representaciones sociales del régimen militar y de las comisiones de la verdad en Sudamérica.

Palabras clave: memoria colectiva, representaciones sociales de la historia, redes sociales, justicia transicional, comisiones de la verdad. 


\section{Introduction}

Many countries in Latin America were ruled by authoritarian military regimes in the second half of the $20^{\text {th }}$ century, such as Brazil (from 1964 to 1985). These regimes were a consequence of Cold War conflicts between leftist socialists or communists and rightist conservatives (Agassiz 2007, 177). The transition to a democratic government in Brazil was based on an amnesty law, which prevented the investigation of the human rights violations perpetrated. Only 27 years after, in 2012, a Truth Commission - TC - was created with the aim of revealing the truth about the dictatorial regime. However, since the publication of its its final report, revisionist far-right responses increased in acceptance in Brazil, resulting in the election of Jair Bolsonaro (a congressman who denies the existence of a dictatorship or human rights violations during this period) for president in October 2018 with $55.1 \%$ of the votes.

Although history textbooks still represent the military regime negatively (Bezerra 2017,9), revisionist books representing it more positively have become popular (Calil 2014, 1) and support for democracy has dropped in Brazil (Corporación Latinobarómetro 2020). Considering that the increase of revisionism seems to start right after the release of the Truth Commission's final report, it is important to analyze its impact at that time. In this regard, we intend to analyze the spontaneous discourse employed by Internet users in news comments about the final report by means of the social representations theory approach.

\section{Truth commissions: overcoming a violent past}

Truth Commissions are transitional justice procedures that have been carried out in more than 50 countries. Their main functions are: to reveal the truth about a violent past; to contribute to creating an integrative history that considers the different narratives about the past; to prevent new conflicts from arising and, sometimes, to promote justice for the victims (Hayner 2011, 8). In Brazil, its main goal was "to examine and clarify the serious human rights violations (...) aiming at accomplishing the right to memory and historical truth and to promote a national reconciliation" (Comissão Nacional da Verdade 2014, 15). Its work was not aimed at prosecuting the perpetrators. The final report, released in December 2014, concluded that the military regime in Brazil was directly responsible for 434 murders and disappearances, 
1843 torture cases, and the restriction of the citizens' political rights (Comissão Nacional da Verdade 2014, 17).

South American authoritarian regimes have been proved to have had an impact on people's personal lives (Concha et al. 2009, 55; Oddone and Lynch 2008, 134; Paredes and Oberti 2015, 153). Previous studies about the TCs' impact in South America show that they are perceived as effective when there is sympathy for the victims, institutional trust, and a positive social climate (Arnoso et al. 2015, 291; Cárdenas et al. 2016, 433). Opinions about the TCs can also be related to changes in the representations of history, being the context of the country an important variable in creating integrative narratives about the past (Arnoso et al. 2015, 292). Many variables can be relevant to the elaboration of different representations about the past such as the degree of knowledge about the past held by those who did not live through it (Haye et al. 2013, 77), the current political discourse (Reyes et al. 2013,167) or the representations of other aspects of the past such as the human rights violations (Arnoso and Pérez-Sales 2013, 55).

\section{Social representations of history}

A useful approach to study these kinds of phenomena is the Social Representations Theory (Moscovici 2012, 27). The social representations can be defined as:

"a system of values, ideas and practices with a twofold function; first, to establish an order which will enable individuals to orient themselves in their material and social world and to master it; and secondly to enable communication to take place among the members of a community by providing them with a code for social exchange and a code for naming and classifying unambiguously the various aspects of their world and their individual and group history." (Moscovici 2009, 21)

Social representations are constructed through communication, sometimes challenging the official history (Ahonen 1997, 49). On the individual level, unknown phenomena or themes, such as the Truth Commission in Brazil, engender a need to assign them some meaning. This occurs through two processes: anchoring and objectification. Through anchoring, the unknown idea is categorized within the existing models. For instance, representations of the TC could be anchored on the representations about the president who carried it 
out. The objectification process aims at transforming a concept that is initially abstract into an image, something easy to be remembered and diffused (e.g. Che Guevara as a symbol of communism in Latin America) (Moscovici 2009, 61). On the other hand, at the social level, the different social representations of a topic tend to reach a consensus, although many times the hegemonic representation can coexist with minority representations (Sá et al. 2009, 166).

Social representations theory aims at analyzing how scientific theories are assimilated and changed by common sense (Moscovici 2012, 101). History, like any other discipline, does not escape these transformations. It is often questioned and distorted to achieve political goals and it drives political behavior (Bar-Tal 2007, 1436; Liu and Hilton 2005,540 ) being often used to justify and legitimate current demands and attitudes (Bobowik et al. 2014, 11; Liu, et al. 2014, 60). Building a widely accepted representation of the past has been proved to be very important to maintain a peaceful society or for the reconciliation of groups once in conflict (Bar-Tal and Halperin 2011, 120).

The establishment of democratic governments or their interruption have been shown as essential elements to represent a nation's past (Bombelli et al. 2013, 78; Fernández et al. 2013, 116; Huang et al. 2004, 158; Nencini 2011, 116). In Brazil, the social representations of the authoritarian government of Getúlio Vargas (1937-1945) show the progressive oblivion of this regime and the tendency not to consider him as a dictator; in addition, the connection of this phenomenon with lower levels of education and political participation (Naiff et al. 2008, 115). Regarding the military regime, its representation varies according to age, political positioning, and educational level as well. Although the overall representation is critical (e.g. stressing the human rights violations), some young people may represent it in a more abstract, and sometimes, distorted way (e.g. they sometimes point out a nonexistent war) (Sá et al. 2009, 164). On the other hand, elders show ambivalent opinions. A representation of the military regime as a controlled good time has a significant presence in this group, alongside a critical representation, though it is also present as a minority representation among young people. Right-wing positionings and low educational levels also seem to be related to a more positive view of the past regime (Sá et al. 2009, 165-167). During the years after the end of the military regime, right-wing political parties seemed to have adopted the strategy of distancing themselves from it (Madeira and Tarouco 2010,6). However, the rising of Jair Bolsonaro might be evidence that this position could be changing in Brazil. It can be considered as part of similar right-wing political movements 
around the world such as Donald Trump in the United States, Marine Le Pen in France, Viktor Orbán in Hungary, or Rodrigo Duterte in The Philippines. Many reasons have been considered to explain the rising of these movements (Muis and Immerzeel 2017, 912). The strongest evidence comes from cultural and economic issues (Georgiadou et al. 2018, 110; Inglehart and Norris 2016, 13). An explanation to the rising of the far right that is gaining support is the influence of social media and online interactions to give voice to radicals and put them into contact (Engesser et al. 2017, 5). Therefore, studying these interactions seems to be very important to understand these movements, especially when trying to construct an agreed and solid version of the past to avoid future conflicts.

\section{Public opinion, online interaction, and misinformation}

Communication processes are the basis for constructing knowledge about the social world, and different kinds of communication can result in different ways of representing an object (Moscovici 2012, 86). In this regard, the Internet can be a space of rumors, fake news, or conspiracy theories (Tornberg 2018, 2). It can bolster political trends and changes in public opinion (Bovet et al. 2018, 5). Comments in news websites represent an opportunity to analyze opinions about a social issue, especially if they are polemic. The tendency to give opinions online seems to be related to more participation in political activities outside the virtual environment (Boulianne 2015, 534). However, online comments can be biased by, for instance, gender (Mitchelstein 2011, 2019). Although comments cannot be considered as representatives of the general population's opinions, they can represent the opinions held by large segments of society, and they can influence readers (Henrich and Holmes 2013, 1). In this regard, people deeply engaged with a topic tend to think that public opinion is on their side when they mostly read comments congruent with their point of view (Lee 2012,39).

Additionally, exposition to radicalized comments can lead to an increase in radicalization (Anderson et al. 2014, 381; Santana 2014, 27). People tend to express more their opinion when they think that the public opinion is on their side, and they tend to withhold it when they think the opposite (Liu and Fahmy 2011, 52). Some psychosocial processes can support misinformation online and offline. At least two cognitive biases could be related to these processes: priming and confirmation bias. The first confuse familiarity with truth making information that is widely spread and repeated seem trustful; the last 
refers to the tendency to continue to believe in the same things, ignoring new information opposing one own belief (Kahneman 2011, 15).

In the Brazilian case, the TC was carried out to construct an integrative narrative about the past and to prevent new conflicts from arising. Constructing a shared representation of history has been shown as a crucial step towards the maintenance of peace and democratic rule. Considering that news comments could generate political engagement and change public opinion, we aimed at analyzing how the news about the Brazilian TC report release was commented online.

Although this is an exploratory study, we can posit the following hypothesis:

- H1: positive discourses regarding the TC will be prevalent because TCs are positively evaluated in South America (Mathias et al. 2020,8) as well as in Brazil where most of the people represent the dictatorship negatively (Sá et al. 2009, 164).

- H2: criticism against the TC, although a minority, will also be found due to minority positive social representations regarding the dictatorship are still found in Brazil (Sá et al. 2009, 165) and the online environment favors the expression of polemic minority opinions (Tornberg 2018, 2).

\section{Method}

\subsection{Procedure and sample}

We conducted exploratory documentary research from the collection of comments about the news covering the release of the Brazilian TC report. We made the collection on two newspapers websites ("Folha de São Paulo" and "O Globo") and another newspaper Facebook page ("O Estado de São Paulo"). These are the most read newspapers with national coverage in Brazil, summing up 15 million followers on Facebook (Associaçao Brasileira de Jornais 2018). Anonymous comments were possible on the two websites. On Facebook, it is difficult (although it is not impossible) to comment anonymously. That would require having to create an anonymous profile. Most of the comments analyzed on Facebook were from non-anonymous profiles.

We collected the comments during the 48 hours following the news release. The news had similar content, mentioning the results of the TC work, remembering its goals, and they mentioned the president's discourse remembering the victims and the importance of revealing the truth in order not to repeat the violations. She also 
affirmed to reject any revenge (she was a victim of the military regime, being tortured by government agents).

The news elicited 322 comments on the three newspapers (Folha de São Paulo, $N=82$; O Globo, $N=66$; O Estado de São Paulo, $N=174$ ) during the 48 hours following. We discarded repeated comments, the ones that only tagged other people, as well as the comments not related to the subject.

\subsection{Data analysis}

We transcribed the comments into a textual corpus which we submitted to an analysis using the software Alceste. This software conducts a statistical lexical analysis that seeks to identify repetitive language patterns, looking for the organization of the discourse (Kalampalikis and Moscovici 2005, 15) allowing the analysis of its content. First, the text is decomposed into groups of words or phrases called elementary contextual units. Then, the clusters obtained through a Descendant Hierarchical Analysis provide a visualization of the social representations about the topic (Veloz et al. 1999, 488).

\section{Results}

Once the corpus was analyzed, 456 Elementary Context Units (ECUs) emerged. From the ECUs obtained, 77\% was retained by the software to analyze, corresponding to 9799 words, from which 2,823 were different forms. The analysis considered the words with frequency bigger than the mean of occurrences by word $(M=3.47)$ and the ChiSquare (measuring the link between element and class) above 3.84 $(d f=1, p \geq 0.05)$.

The Descendant Hierarchical Analysis structured the corpus in three classes (Figure 1). In the first step, the corpus was split into two subcorpora, the group comprised of classes 1 and 3 on the left side as opposed to class 2 on the right side. In the second step, the second sub-corpus was divided in two, dividing classes 1 and 3.

Analyzing the thematic contexts shown in Figure 1, we can infer that the conjunct of classes revealed by Descendant Hierarchical Analysis feature Internet users' shared knowledge about the TC, showing that each class holds particularities that comprise the social representations about this subject. The classes' features are, next, described and discussed. 
Figure 1

\section{Classes emerged from the Descendant Hierarchical Analysis on the comments on news about the Brazilian Truth Commission report release}

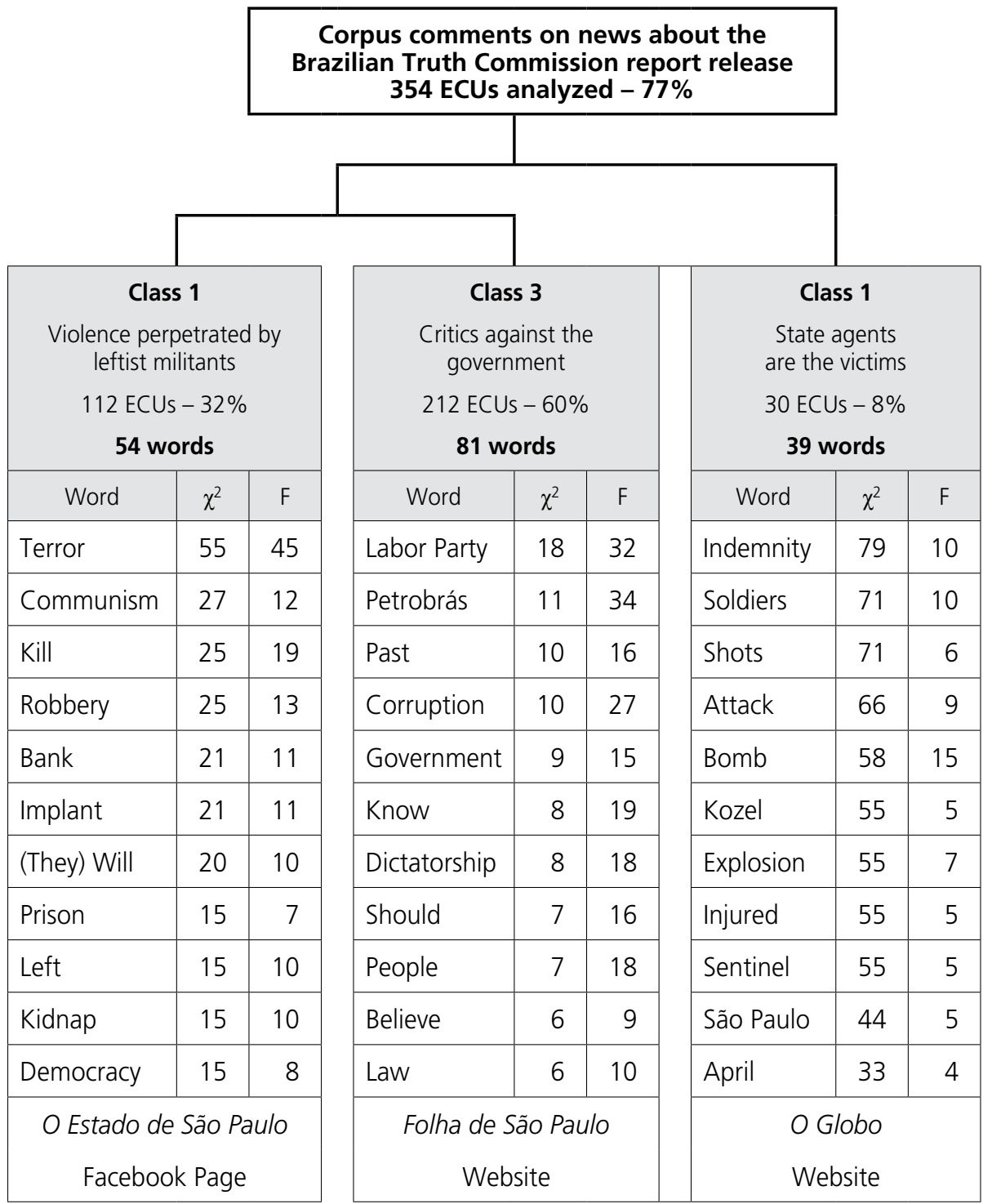

Source: Elaborated by the authors from the output given by the software Alceste. 
The class 1, named Violence perpetrated by leftist militants, was generated from 112 ECUs, corresponding to $32 \%$ of total ECUs. It covered radical words such as terror $\left(\chi^{2}=55\right)$, communism $\left(\chi^{2}=27\right)$, kill $\left(\chi^{2}=25\right)$, robbery $\left(\chi^{2}=25\right)$, bank $\left(\chi^{2}=21\right)$, implant $\left(\chi^{2}=21\right)$, (they) will $\left(\chi^{2}=20\right)$, prison $\left(\chi^{2}=15\right)$, left $\left(\chi^{2}=15\right)$, kidnap $\left(\chi^{2}=15\right)$ and democracy $\left(\chi^{2}=15\right)$. This classes represented mainly comments from Facebook users on "O Estado de São Paulo" page. The most representative examples of this class discourses are:

"(...) (They) were subversive of the public order, terrorists who practiced robberies against banks, houses, shipping companies and quarters, they kidnapped and tortured ambassadors, they killed many people, and also they sentenced many fellows."

(Comment 159;

O Estado de São Paulo; $\chi^{2}=26$ )

"(...) When will they point out the crimes of terrorism and kidnapping made by the Commies?"

(Comment 263;

O Estado de São Paulo; $\chi^{2}=22$ )

"(...) Dilma was a terrorist, bank robber, kidnapper of authorities and maybe murderer in the trials that terrorists of VAR-Palmares made in their apparatus, the terrorists, inebriated by the communism."

(Comment 185;

O Estado de São Paulo; $\chi^{2}=19$ )

"(...) Do they remember a certain murderer, a bank robber who exploded bombs around and today continues to implant terror in Brazilian? Shame on, Brazil!"

(Comment 149;

O Estado de São Paulo; $\chi^{2}=13$ )

In this class, TC is perceived as linked to the leftist organizations that existed during the regime, being partial because of that. Although the news about the TC report release described its goal as the investigation of the human rights violations committed by the military government, this class presents the alleged crimes committed by leftist organizations. These organizations are evaluated as terrorists and users claim that their crimes should also have been investigated. It was observed that the kidnapping of the American ambassador Charles Elbrick had a substantial impact on the discourse against the leftist 
organizations, as well as murders attributed to them. President Dilma Rousseff was also related to these organizations and crimes, suggesting she has no right or lacks moral virtue to conduct an investigation about this period, although she denies these crimes (Folha de São Paulo 2009) and she was only convicted of subversion by the military regime.

Related to class 1, class 3 "Criticism against the government" comprised 212 ECUs (60\% of total ECUs). The word radicals that represent this class were: PT (Labor Party - Party of the President Rousseff) $\left(\chi^{2}=18\right)$, Petrobrás (State-owned oil company - Object of a corruption scandal) $\left(\chi^{2}=11\right)$, past $\left(\chi^{2}=10\right)$, corruption $\left(\chi^{2}=10\right)$, government $\left(\chi^{2}=9\right)$, know $\left(\chi^{2}=8\right)$, dictatorship $\left(\chi^{2}=8\right)$, should $\left(\chi^{2}=7\right)$, people $\left(\chi^{2}=7\right)$, believe $\left(\chi^{2}=6\right)$, law $\left(\chi^{2}=6\right)$, politics $\left(\chi^{2}=6\right)$, Petrobrás Scandal $\left(\chi^{2}=6\right)$. This class represents mainly the comments on the "Folha de São Paulo" website. Comments in this class were focused on the current problems, mainly the corruption scandal which came out during this year. Some comments only expressed their dissatisfaction with the government, meanwhile, others expressed their suspects that the TC would be an attempt to divert attention from the corruption scandals, although it was implemented in 2012 and the publication date was defined beforehand. Thus, the focus in this class is the present, sometimes comparing it with Rousseff and the leftist organization's past, which comprise its link with Class 1 . The most representative examples of this class are:

(...) The Truth Commission is not above the Brazilian constitution; she has to be impartial and observe that in the past there were exaggerations by both sides and each side has an explanation according to their conveniences and moments.

(Comment 233;

O Estado de São Paulo; $\chi^{2}=16$ )

(...) The only thing people want to know is the truth about Celso Daniel's (a Labor Party politician murdered) death, Lula's (Brazilian ex-president, also from Labor Party) family patrimony, and especially about the Petrobrás scandal, this robbery that was promoted by the criminal organization Labor Party during its 12 years of government.

(Comment 68;

O Globo; $\chi^{2}=12$ )

(...) I want to know about the Truth Commission of Petrobrás Scandal and about the dirty money that elects this woman.

(Comment 71;

O Globo; $\chi^{2}=12$ ) 
(...) Funny, every time Dilma touched in her speech is on Globo (Television Broadcast), why do not they show the people asking her to get out?

(Comment 310;

O Estado de São Paulo; $\chi^{2}=12$ )

(...) Ms. Dilma knows how to be false the way she did in her campaign promises, Ms. Dilma cultivates the hate the way she did against their opponents in the last elections. What hypocrisy! However, nobody believes in your bullshits and lies Ms. Dilma.

(Comment 4; Folha de São Paulo; $\chi^{2}=10$ )

The last class, which was named "State agents are the victims" comprised 30 UCEs (8\%) and represented mainly the comments of "O Globo" website. The content included the word radicals: indemnity $\left(\chi^{2}=79\right)$, soldiers $\left(\chi^{2}=71\right)$, shots $\left(\chi^{2}=71\right)$, attack $\left(\chi^{2}=66\right)$, bomb $\left(\chi^{2}=58\right)$, Kozel (state agent dead in an attack organized by leftist organizations, allegedly, as users say, with the participation of President Rousseff) $\left(\chi^{2}=55\right)$, explosion $\left(\chi^{2}=55\right)$, injured $\left(\chi^{2}=55\right)$, sentinel $\left(\chi^{2}=55\right)$, São Paulo $\left(\chi^{2}=44\right)$, April $\left(\chi^{2}=33\right)$. The most representative examples of this class are:

(...) This cry is a hoax, crocodile tears, or is she crying by Kozel, dead on an attack with her participation?

(Comment 50;

Folha de São Paulo; $\chi^{2}=81$ )

(...) April 15th, 1968, bomb-throwing against the old army headquarter in São Paulo, Conselheiro Crispiano street, with two causalities, April 20th 1968 , another bomb attack against the newspaper O Estado de São Paulo.

(Comment 175;

O Estado de São Paulo; $\chi^{2}=71$ )

(...) Antonio's family never received any indemnity or tear of this failed crocodile.

(Comment 103;

O Globo; $\chi^{2}=70$ )

As in the other classes, the main motif is the critics against the TC. However, in this class, the critics are more focused on the president's 
role during the regime as a member of a leftist organization than in the TC's work. If in class 1 the focus was on the violence committed by the leftist organizations, in class 3 is clearer the defense of state agents. They are described as victims of attacks perpetrated by these organizations. Soldier Mario Kozel is frequently remembered as one of these victims, and President Rousseff is associated with this attack, although she denies it and was never officially accused of it, even by the dictatorship. Thus, their tears are seen as false, because she is apologizing as a chief of state for the crimes committed by the state against citizens but, in the evaluation of these users, she should apologize for the crimes committed by the leftist organizations. Another sensible question was the indemnity received by President Rousseff. Users' comments argued that the families of state agents dead in attacks organized by leftist organizations should also receive indemnities.

\section{Discussion}

Contrary to $\mathrm{H} 1$, which stated that positive discourses about the Brazilian Truth Commission would prevail on the Internet comments, the first aspect that immediately stands out in the results is the criticism towards the Truth Commission presented in the three classes. Comments were, in general, extremely negative about the TC and they differed only about the aspect criticized. Some of the critics indirectly justified the human rights violations committed by the military regime. In this regard, it is important to bear in mind that a third of Brazilians do not fully support democracy, and a fifth support the use of torture by state agents (Datafolha 2014).

Ideological identification seems to play an essential role in the social representations about the TC and the past. The negative evaluations about President Rousseff, Labor Party, and leftists seem to anchor the negative social representations about the TC work and its report. These negative evaluations seem to be radicalized since the corruption scandals that came out in 2014. They seem to objectify Rousseff and the leftist militants as bandits or terrorists, Labor party as corrupt and, because so, torture against them or their supporters may be justified according to some users. The negative representations of the leftists seem to be anchoring a positive social representation of the military regime. The positive view about the regime that was the minority in 2005 (Sá et al. 2009, 165) seems to be increasing in acceptance. 
Some explanations for the difference in the social representations about the military regime between 2005 and 2014 can be drawn. Firstly, Internet users may comprise a different population than the general one (Mitchelstein 2011, 2019). In the scope of this study, it is challenging to establish if the opinions shared represent what the overall population thinks. Although Internet use is growing in Brazil, only $55 \%$ of households had permanent access to the Internet in 2014 (IBGE 2015). Moreover, access to the Internet was higher in wealthier households (90\%) than in the poorer (29\%) (IBGE 2015). If we consider that Labor Party was more popular among the poor (G1 2014) it can help to explain the results. Accordingly, a poll on Folha de São Paulo's Website showed that only $22 \%$ of the readers voted for Dilma Rousseff in the 2014 elections (compared with 38\% of all voters who had voted for her) (Folha de São Paulo 2015). However, even if the comments do not represent the overall population opinion they may represent the opinions of those who have more participation in political activities offline (Boulianne 2015, 534).

Moreover, the first comments may have influenced those who agree to express their opinion (Lee 2012, 39) even increasing the radicalization of the discourse (Anderson et al. 2014, 381) and those who disagree to withhold it (Liu and Fahmy 2011, 52). Indeed, the three classes referred to the previous comments on each of the three newspapers analyzed indicating some resonance of the first comments.

Finally, the results may be explained by a change in the social representations about the military regime since 2005 . The social representations of history are especially sensitive to current social demands (Liu et al. 2014, 60). Moreover, the generational change is going on 50 years after the coup that established the military regime in Brazil. Therefore, those who lived this event as adults are giving place to the new generation who are learning about the past from elders' narratives or the history books. The generational change is the time when the different memories should converge to a consensual social representation of the past (Assmann 2008, 111). However, the political climate in Brazil in 2014 was radicalized, and one of its central figures (President Dilma Rousseff) was also a significant figure during the military regime period. Thus, the current negative opinions and beliefs about President Dilma Rousseff and the leftism might be anchoring the social representations about the past. Political positioning partially anchored social representation about the military regime in 2005 (Sá et al. 2009, 166), however, in 2014 it seems that radicalization about the political situation was affecting the overall representation of the regime. 
History provides a coherent and legitimated narrative that is taught in schools to the next generations. What should be taught is an object of tensions and discussions. The TC, which has one of its goals to create an integrative narrative that includes all sides of the conflict (Comissão Nacional da Verdade 2014, 15) may have failed on this objective. The long-time passed between the end of the military regime, and the TC implementation might have influenced how people represented the TC compared with other countries such as Argentina and Chile. In these countries, the TC was part of the same movement that put an end to the dictatorship (Hayner 2011, 45), and thus, they were implemented in a context of social support. The opposite occurred in Brazil, where the $\mathrm{TC}$ released its report in a context of radicalization of the political positions and high rejection of both, President Rousseff and leftism. In this context, putting the authoritarian past on the agenda might have had a counter-productive effect. The comments did not recognize as truth what the TC revealed. They questioned even the consensual aspects of the regime, such as that it was a negative period with many human rights violations (Sá et al. 2009, 164). Some comments even questioned if there was a dictatorship.

\section{Conclusions}

The opinions expressed about the TC report did not reflect its content but previous social representations about the $\mathrm{TC}$, the government, the president, and the military regime. For instance, even if the TC report has more than 3000 pages, people were giving opinions about it seconds after its release. This phenomenon is in accordance with the cognitive bias of ignoring or distorting the information that goes against one's beliefs (Kahneman 2011, 15). Indeed, in the three classes, the words "Truth Commission" or "report" were not present among the ten more mentioned words.

Thereby, it seems that the TC did not accomplish its goals among the public who are motivated to speak out online. Although its report reveals many violations committed by the military regime, these findings were not recognized as truth. Thus, the TC seems not to have helped to build an integrative history; rather, it seems to have boosted revisionism on the consensual elements of the social representations of the past. Therefore, it is difficult to believe that the TC has helped to prevent new conflicts from arising.

Finally, we have to take into account the limits of this study. Firstly, the results probably do not represent the social representation of the 
overall population. As discussed, Internet users probably comprise a different population than the general one. Thus, it would be interesting to investigate the social representations of history in a representative sample, also aiming at comparing it with the previous research to analyze changes. Moreover, we collected the comments in a radicalized context, so, it would be important to investigate the Truth Commission evaluation as well as the social representations about the past in a quieter political time to better evaluate their effects in a long-term perspective.

\section{References}

Agassiz, Almeida. 2007. A Ditadura Dos Generais: Estado Militar Na América Latina: O Calvário Na Prisão. Rio de Janeiro: Bertrand Brasil.

Agência Senado. 2019. "Texto que aponta 'esquerdismo' no jornalismo causa polêmica no CCS.» Senado Notícias. Accessed November 20, 2021. https://www12.senado.leg.br/noticias/materias/2019/11/04/texto-queaponta-hegemonia-esquerdista-no-jornalismo-causa-polemica-no-ccs.

Ahonen, Sirkka. 1997. "A transformation of History: The official representations of History in East Germany and Estonia, 1986-1991.»Culture and Psychology 3, no 1: 41-62. https://doi.org/10.1177/1354067X9700300103. Anderson, Ashley A., Dominique Brossard, Dietram A. Scheufele, Michael A. Xenos, and Peter Ladwig. 2014. "The 'nasty effect:' Online incivility and risk perceptions of emerging technologies.» Journal of ComputerMediated Communication 19, no. 3: 373-87. https://doi.org/10.1111/ jcc4.12009.

Arnoso, Maitane, Darío Páez, Manuel Cárdenas, Elena Zubieta, Agustín Espinosa, and Marian Bilbao. 2015. «Representaciones sociales del pasado y rituales de justicia transicional en América Latina.» Cadernos de Pesquisa 45, no. 156: 276-98. https://doi.org/10.1590/198053143134.

Arnoso, Maitane, and Pau Pérez-Sales. 2013. «Representaciones sociales de la víctima: entre la inocencia y la militancia política.» Psicoperspectivas. Individuo y Sociedad 12, no. 1: 50-71. https://doi.org/10.5027/ psicoperspectivas-Vol12-Issue1-fulltext-221.

Assmann, Jan. 2008. "Communicative and Cultural Memory.» In Cultural Memory Studies. An International and Interdisciplinary Handbook, edited by Astrid Erll and Ansgar Nunning, 109-18. New York: Walter de Gruyter. https://doi.org/10.1515/9783110207262.2.109.

Associação Brasileira de Jornais. 2018. Tiragem impressa dos maiores jornais perde 520 mil exemplares em 3 anos. Accessed January 10, 2020. https://www.anj.org.br/site/menagenda/97-midia-nacional/5251-tiragemimpressa-dos-maiores-jornais-perde-520-mil-exemplares-em-3-anos.html.

Azevedo, Fernando A. 2006. "Sistema de mídia e o sistema político.» Opinião Pública 12: 88-113. https://doi.org/10.1590/S0104-62762006000100004. 
Bar-Tal, Daniel. 2007. «Sociopsychological foundations of intractable conflicts.»American Behavioral Scientist 50, no. 11: 1430-53. https://doi. org/10.1177/0002764207302462.

Bar-Tal, Daniel, and Eran Halperin. 2011. «Intergroup conflicts and their resolution.» In Frontiers of Social Psychology. Intergroup Conflicts and Their Resolution: A Social Psychological Perspective, edited by Daniel Bar-Tal, 217-40. New York: Psychology Press. https://doi.org/10.4324/9780203834091.

Bezerra, Ellen. 2017. «A ditadura militar nos livros didáticos: História e memória nos manuais de Ensino de 1976 e 2016.» In XXIX Simpósio Nacional de História, 1-16. Brasília: UNB.

Bobowik, Magdalena, Darío Páez, James Liu, Laurent Licata, Olivier Klein, and Nekane Basabe. 2014. «Victorious justifications and criticism of defeated: Involvement of nations in World Wars, social development, cultural values, social representations of war, and willingness to fight.» International Journal of Intercultural Relations 43 (PA): 60-73. https://doi.org/10.1016/j. ijintrel.2014.08.013.

Bombelli, Juan, Omar Fernández, and Fernanda Sosa. 2013. «Representaciones sociales de la historia argentina y género: Un estudio con estudiantes militares.» Boletín de Psicología 108: 71-89.

Boulianne, Shelley. 2015. "Social media use and participation: A meta-analysis of current research.» Information Communication \& Society 18, no. 5: 524-38. https://doi.org/10.1080/1369118X.2015.1008542.

Bovet, Alexandre, Flaviano Morone, and Hernán A. Makse. 2018. «Validation of twitter opinion trends with national polling aggregates: Hillary Clinton vs Donald Trump.» Scientific Reports 8, no. 1: 8673. https://doi. org/10.1038/s41598-018-26951-y.

Calil, Gilberto G. 2014. «O revisionismo sobre a ditadura Brasileira: A obra de Elio Gaspari.» Segle xx. Revista Catalana d'història. 7: 99-126.

Cárdenas, Manuel, Elena Zubieta, Darío Páez, Maitane Arnoso, and Agustín Espinosa. 2016. «Determinants of approval of the work of Truth Commissions in the Southern Cone: A comparative study.» Revista de Psicología Social 31, no. 3: 423-62. https://doi.org/10.1080/02134748.2016.1190127.

Comissão Nacional da Verdade. 2014. Relatório Da Comissão Nacional Da Verdade. Brasília-DF: Comissão Nacional da Verdade.

Concha, Víctor, Eduardo Guichard, and Guillermo Henríquez. 2009. «Memoria histórica y paradigma del curso de vida. Investigación CEVI-Chile.» Sociedad Hoy 17, no. 2: 51-61. https://doi.org/10.13140/RG.2.1.4664.9765.

Corporación Latinobarómetro. 2020. «Latinobarómetro: Análisis on line.» Accessed September 14, 2021. http://www.latinobarometro.org/latOnline.jsp.

Datafolha. 2014. Democracia e ditadura. São Paulo. Accessed February 14, 2020. http://media.folha.uol.com.br/datafolha/2014/03/31/democracia-xditadura-versao-2.pdf.

Engesser, Sven, Nicole Ernst, Frank Esser, and Florin Büchel. 2017. «Populism and social media: How politicians spread a fragmented ideology.» Information Communication and Society 20, no. 8: 1109-26. https://doi.or g/10.1080/1369118X.2016.1207697. 
Fernández, Omar, Lisandro Cejas, and Alberto Sosa. 2013. «Memoria colectiva y representaciones sociales de la História en estudiantes de Psicología.» In V Congreso Internacional de Investigación y Práctica Profesional en Psicología XX Jornadas de Investigación Noveno Encuentro de Investigadores en Psicología del MERCOSUR. Facultad de Psicología Universidad de Buenos Aires, Buenos Aires, 114-17.

Folha de São Paulo. 2015. 61\% Dos Leitores Da Folha Querem Renúncia de Dilma, Aponta Datafolha. Accessed February 14, 2020. https://www1. folha.uol.com.br/poder/2015/10/1693643-61-dos-leitores-queremrenuncia-de-dilma.shtml.

Folha de São Paulo. 2009. Dilma diz não ter a mesma cabeça da época em que era guerrilheira. Accessed February 14, 2020. http://www1.folha.uol.com. br/poder/2009/04/545690-dilma-diz-nao-ter-a-mesma-cabeca-da-epocaem-que-era-guerrilheira-veja-a-integra-da-entrevista.shtml.

Georgiadou, Vasiliki, Lamprini Rori, and Costas Roumanias. 2018. «Mapping the European far right in the 21st Century: A meso-level analysis.» Electoral Studies 54: 103-15. https://doi.org/10.1016/j.electstud.2018.05.004.

Haye, Andres, Jorge Manzi, Roberto González, and Héctor Carvacho. 2013. «Teorías infantiles del Golpe de Estado 25 años después de los hechos.» Psykhe 22, no. 2: 67-81. https://doi.org/10.7764/psykhe.22.2.607.

Hayner, Priscilla B. 2011. Unspeakable Truths - Transitional Justice and the Challenge of Truth Commissions. 2nd ed. New York: Routledge.

Henrich, Natalie, and Bev Holmes. 2013. "Web news readers' comments: Towards developing a methodology for using on-line comments in social inquiry.» Journal of Media and Communication Studies 5, no. 1: 1-4. https://doi.org/10.5897/JMCS11.103.

Huang, Li-Li, James Liu, and M L Chang. 2004. "'The double identity' of Taiwanese Chinese: A dilemma of politics and culture rooted in History.» Asian Journal of Social Psychology 7, no. 2: 149-68. https://doi. org/10.1111/j.1467-839x.2004.00141.x.

IBGE. 2015. Acesso à Internet e à Televisão e Posse de Telefone Móvel Celular Para Uso Pessoal Accessed February 14, 2020. https://biblioteca.ibge.gov. br/biblioteca-catalogo?id=293373\&view=detalhes.

Inglehart, Ronald, and Pippa Norris. 2016. "Trump, Brexit, and the rise of populism: economic have-nots and cultural backlash.» SSRN Electronic Journal RWP16 (026): 1-53. https://doi.org/10.2139/ssrn.2818659.

Kahneman, Daniel. 2011. Thinking Fast and Slow. New York: Farrar, Straus and Giroux.

Kalampalikis, Nikos, and S. Moscovici. 2005. «Une approche pragmatique de I'analyse Alceste.» Les Cahiers Internationaux de Psychologie Sociale. https://doi.org/10.3917/cips.066.0015.

Lee, Eun Ju. 2012. "That's not the way it is: how user-generated comments on the news affect perceived media bias.» Journal of Computer-Mediated Communication 18, no. 1: 32-45. https://doi.org/10.1111/j.10836101.2012.01597.x. 
Liu, James, Chris G. Sibley, and Li-Li Huang. 2014. «History matters: Effects of culture-specific symbols on political attitudes and intergroup relations.» Political Psychology 35, n. 1: 57-79. https://doi.org/10.1111/pops. 12027.

Liu, Xudong, and Shahira Fahmy. 2011. «Exploring the spiral of silence in the virtual world: Individuals' willingness to express personal opinions in online versus offline settings. » Journal of Media and Communication Studies 3, no. 2: 45-57. https://doi.org/10.5897/JMCS.9000031.

Liu, James, and Denis J. Hilton. 2005. "How the past weighs on the present: Social representations of History and their role in identity politics.» British Journal of Social Psychology 44 (Pt 4): 537-56. https://doi. org/10.1348/014466605X27162.

Madeira, Rafael, and Gabriela Tarouco. 2010. "A 'direita envergonhada' no Brasil: Como partidos reinterpretam seus vínculos com o regime militar?»In V Congreso Latinoamericano de Ciencia Política. Asociación Latinoamericana de Ciencia Política. Buenos Aires. http://www.aacademica. org/000-036/804.

Mathias, Anderson, Darío Páez, Agustín Espinosa, Salvador Sandoval, Carolina Alzugaray, Maitane Arnoso, and Manuel Cárdenas. 2020. «The association between Truth Commissions Evaluation, emotional climate and institutional trust: Comparison and meta-analysis of surveys in six South American countries.» Revista de Psicologia Social 35, no. 2: 203-45. https://doi.org/10.1080/02134748.2020.1721053.

Mitchelstein, Eugenia. 2011. «Catharsis and community: Divergent motivations for audience participation in online newspapers and blogs.» International Journal of Communication 5, no. 1: 2014-34.

Moscovici, S. 2009. Representações Sociais: Investigações Em Psicologia Social. 6th ed. Petrópolis - RJ: Vozes.

Moscovici, S. 2012. A Psicanálise, Sua Imagem e Seu Público. 10th ed. Petrópolis - RJ: Vozes (Original work published in 1961).

Muis, Jasper, and Tim Immerzeel. 2017. "Causes and consequences of the rise of populist radical right parties and movements in Europe.»Current Sociology 65, no. 6: 909-30. https://doi.org/10.1177/0011392117717294.

Naiff, Denis, Celso Pereira de Sá, and Luciene alvez Miguez Naiff. 2008. «A memória social do Estado Novo em duas gerações.» Psicologia: Ciência e Profissão 28, no. 1: 110-21.

Napolitano, Marcos. 2017. «A imprensa e a construção da memória do regime militar Brasileiro (1965-1985).» Estudos Ibero-Americanos 43, no. 2: 346-66. https://doi.org/10.15448/1980-864X.2017.2.24766.

Nencini, Alessio. 2011. "Social representations of National History: Stability and changeability between different generations of Italians over a period of three years.» Societal and Political Psychology International Review 2, no. 1: 111-26.

Oddone, María Julieta, and Gloria Lynch. 2008. «Las memorias de los hechos Socio-Históricos en el curso de la vida.» Revista Argentina de Sociología 6, no. 10: 121-42. 
Paredes, Mariana, and Patricia Oberti. 2015. «Eventos sociohistóricos en la vida de los Uruguayos: Una perspectiva generacional.» Revista de Ciencias Sociales 28, no. 36: 145-68.

Reyes, María José, Juan Muñoz, and Félix Vázquez. 2013. «Políticas de Memoria desde discursos cotidianos: La despolitización del pasado reciente en el Chile actual.»Psykhe 22, no. 2: 161-73. https://doi.org/10.7764/ psykhe.22.2.582.

Sá, Celso Pereira de, Denize Cristina de Oliveira, Ricardo Vieralves de Castro, Renata Vetere, and Rafael Vera Cruz de Carvalho. 2009. "A memória histórica do regime militar ao longo de três gerações No Rio de Janeiro: Sua estrutura representacional.» Estudos de Psicologia (Campinas) 26, no. 2: 159-72. https://doi.org/10.1590/\$0103-166X2009000200004.

Santana, Arthur. 2014. "Virtuous or vitriolic: The effect of anonymity on civility in online newspaper reader comment boards.» Journalism Practice 8, no. 1: 18-33. https://doi.org/10.1080/17512786.2013.813194.

Törnberg, Petter. 2018. "Echo chambers and viral misinformation: Modeling fake news as complex contagion.» PLOS ONE 13, no. 9: 1-21. https://doi. org/10.1371/journal.pone.0203958.

Veloz, Maria Cristina Triguero, Clélia Maria Nascimento-Schulze, and Brigido Vizeu Camargo. 1999. "Representações sociais do envelhecimento.» Psicologia: Reflexão e Crítica 12, no. 2: 479-501. https://doi.org/10.1590/ S0102-79721999000200015. 


\section{Copyright}

Deusto Journal of Human Rights / Revista Deusto de Derechos Humanos is an Open Access journal; which means that it is free for full and immediate access, reading, search, download, distribution, and reuse in any medium only for non-commercial purposes and in accordance with any applicable copyright legislation, without prior permission from the copyright holder (University of Deusto) or the author; provided the original work and publication source are properly cited (Issue number, year, pages and DOI if applicable) and any changes to the original are clearly indicated. Any other use of its content in any medium or format, now known or developed in the future, requires prior written permission of the copyright holder.

\section{Derechos de autoría}

Deusto Journal of Human Rights / Revista Deusto de Derechos Humanos es una revista de Acceso Abierto; lo que significa que es de libre acceso en su integridad inmediatamente después de la publicación de cada número. Se permite su lectura, la búsqueda, descarga, distribución y reutilización en cualquier tipo de soporte sólo para fines no comerciales y según lo previsto por la ley; sin la previa autorización de la Editorial (Universidad de Deusto) o la persona autora, siempre que la obra original sea debidamente citada (número, año, páginas y DOI si procede) y cualquier cambio en el original esté claramente indicado. Cualquier otro uso de su contenido en cualquier medio o formato, ahora conocido o desarrollado en el futuro, requiere el permiso previo por escrito de la persona titular de los derechos de autoría. 